A C T A C H E M I C A S C A N D I N A V I C A $12 \quad$ (1958) $438-446$

\title{
The Interaction of Riboflavin, FMN, and FAD with Various Metal Ions: The Riboflavin Catalyzed Photochemical Reduction of $\mathrm{Fe}^{\mathrm{III}}$, and Photooxidation of $\mathrm{Fe}^{\mathrm{II}}$
}

\author{
W ILLIAM J. R UTTER*
}

Medicinska Nobelinstitutet, Biokemiska avdelningen, Stockholm, Sweden, and Division of Biochemistry, University of Illinois, Urbana, Illinois, USA

(1) The fluorescence of riboflavin, FMN, and FAD solutions is quenched by certain divalent and trivalent metal ions. Of the ions tested, $\mathrm{HgII}$ and FeII, FeIII, CoIII, and AuIII were particularly effective.

(2) Riboflavin, FMN, and FAD solutions catalyze a photooxida. tion of $\mathrm{FeII}$ ions and a photoreduction of FeIII ions.

(3) The riboflavin catalyzed photoreduction of $\mathrm{Fe} I \mathrm{II}$ is inhibited by oxygen, while the photooxidation of $\mathrm{Fe} I \mathrm{II}$ is strongly dependent on oxygen. Catalase stimulates both of these processes.

(4) The mechanism of the photochemical reactions and their possible relationship to the function of riboflavin in biological systems is discussed.

Tn certain flavoprotein systems, the fluorescence of the free riboflavin coenIzyme is lost on combination with the apoprotein ${ }^{1,2}$. This fact together with recent observations concerning possible interactions of metal ions in certain flavoprotein systems ${ }^{3,4}$, prompted a study of the effect of various metal ions on the fluorescence of riboflavin, FMN, and FAD **. It was found that $\mathrm{Fe}^{\mathrm{III}}$ was a remarkably effective quencher of the fluorescence of these compounds. An inquiry concerning the mechanism of the quenching phenomenon resulted in the discovery of a riboflavin-catalyzed photoreduction of $\mathrm{Fe}^{\mathrm{III}}$, as well as a riboflavin-catalyzed photooxidation of $\mathrm{Fe}^{\mathrm{II}}$. It is the purpose of this paper to report these observations, and to discuss their significance relative to the functions of riboflavin in biological systems.

\section{MATERIALS AND METHODS}

FMN and FAD were purified by ionophoresis and kindly supplied by B. Rolander. A sample of riboflavin procured from Hoffman-LaRoche was recrystallized for use in these experiments.

Crystalline catalase was procured from Worthington Biochemicals, Inc. Activity was measured by the method of Beers and Sizer ${ }^{5}$. One unit is defined as that amount of

* U.S. Public Health Service Fellow, Medicinska Nobelinstitutet, 1954-1955. Present address: Division of Biochemistry, University of Illinois, USA.

** Abbreviations used: FMN - flavin mononucleotide; FAD - flavin adenine dinucleotide; EDTA - ethylene diamine tetraacetate. 
enzyme which decomposes $1 \mathrm{mg}$ hydrogen peroxide in $1 \mathrm{~min}$ under standard assay conditions.

The concentration of FeII ions was quantitatively determined with the $a, \alpha^{\prime}$-dipyridyl reagent ${ }^{6}$, usually from the difference spectra of appropriate experimental samples.

The intensity of fluorescence was measured with the instrument devised and constructed by Theorell and Nygaard 7. Difference spectra were obtained with the aid of a Cary Recording double beam spectrophotometer.

Photoillumination was accomplished by means of a 250 watt lamp fixed approxima. tely $25 \mathrm{~cm}$ from the incubation fluid. The entire system was enclosed in aluminum foil, and partially filled with water so the temperature of the sample remained essentially constant during the photoillumination period.

\section{RESULTS}

The fluorescence of riboflavin solutions is quenched by a variety of substances including diphenols, purines, and pyrimidines and electrolytes, particularly ${ }^{8} \mathrm{I}^{-}$and $\mathrm{Ag}^{+}$. Weber showed that the remarkably strong quenching effect of silver ions is apparently due to the formation of a complex with riboflavin which is non-fluorescent.

The quenching action of electrolytes on riboflavin fluorescence is not a simple function of the ionic strength, but is a function of the particular ionic species present. Theorell and Nygaard ${ }^{9}$, for example, have found that halogen ions quench the fluorescence of $\mathrm{FMN}$ in the order $\mathrm{I}^{-}>\mathrm{Br}^{-}>\mathrm{Cl}^{-}>\mathrm{F}^{-}$, while $\mathrm{SO}_{4}^{-}, \mathrm{PO}_{4}^{-}$, and $\mathrm{CH}_{3} \mathrm{COO}^{-}$ions did not quench at the concentrations tested. $\mathrm{CaCl}_{2}, \mathrm{KCl}, \mathrm{NaCl}$, and $\mathrm{NH}_{4} \mathrm{Cl}$ were equally effective as quenching agents.

Our initial experiments were concerned with the effect of various di- and trivalent metal ions on the fluorescence of riboflavin. Table 1 presents certain of the data obtained. Most divalent ions tested were much less effective quenching agents than silver ions in this regard. Mercury, however, was more effective than $\mathrm{Ag}^{+}$in quenching the fluorescence of riboflavin. When mercury ${ }^{\mathrm{II}}$ salts were added to aqueous solutions of riboflavin, a light pink color was observed. The color change was similar, but much less pronounced than that produced by silver ions.

Of the trivalent metal ions, $\mathrm{Al}^{\mathrm{III}}$ was ineffective, but $\mathrm{Au}^{\mathrm{III}}$, and especially $\mathrm{Co}^{\mathrm{III}}$, and $\mathrm{Fe}^{\mathrm{III}}$ were remarkably powerful quenching agents. Both $\mathrm{Co}^{\mathrm{III}}$ and $\mathrm{Fe}^{\mathrm{III}}$ salts were much more effective than silver salts in quenching riboflavin fluorescence. These results were somewhat unexpected since Albert ${ }^{10}$ has shown that divalent metals complex much more strongly with riboflavin than their trivalent counterparts. No binding of $\mathrm{Fe}^{\mathrm{III}}$ by riboflavin was detected by Albert, for example. The present data nevertheless indicate an $\mathrm{Fe}^{\mathrm{III}}$ riboflavin reaction in which either a non-fluorescent complex is involved, or in which the lifetime of the excited state is decreased. A plot of the quenching of fluorescence as a function of $\mathrm{Fe}^{\mathrm{III}}$ concentration is presented in Fig. 1. The solid points represent experimentally obtained values, whereas the solid curve represents the theoretical curve which would be expected if the reaction involved is simply: (Riboflavin $+\mathrm{Fe}^{\mathrm{III}} \rightarrow$ [Riboflavin $-\mathrm{Fe}^{\mathrm{III}}$ ]) and the equilibrium constant

$$
K=\frac{[\text { Riboflavin }]\left[\mathrm{Fe}^{\mathrm{III}}\right]}{\left[\text { Riboflavin }-\mathrm{Fe}^{\mathrm{III}}\right]}=4.6 \times 10^{-4}
$$

Acta Chem. Scand. 12 (1958) No. 3 
Table 1. Quenching of riboflavin fluorescence by salts. The experimental cuvettes contained $300 \mathrm{~m} \mu \mathrm{M}$ riboflavin with ions added as indicated. Volume in all cases $3.0 \mathrm{ml}$. $\mathrm{pH}$ adjusted to $5.5-6.0$ with $\mathrm{NaHCO}_{3}$, temperature $30^{\circ} \mathrm{C}$. The fluorescence is presented as per cent fluorescence of a control cuvette containing riboflavin alone.

\begin{tabular}{|c|c|c|}
\hline $\begin{array}{c}\text { Salt } \\
\text { Monovalent cations }\end{array}$ & $\begin{array}{l}\text { Concentration } \\
\text { (M) }\end{array}$ & $\begin{array}{l}\text { Per cent } \\
\text { fluorescence }\end{array}$ \\
\hline $\mathrm{NaNO}_{8}$ & $\begin{array}{l}0.003 \\
0.006 \\
0.01\end{array}$ & $\begin{array}{l}87 \\
79 \\
76\end{array}$ \\
\hline $\mathrm{AgNO}_{2}$ & $\begin{array}{l}0.003 \\
0.006 \\
0.012 \\
0.018\end{array}$ & $\begin{array}{l}72 \\
58 \\
43 \\
31\end{array}$ \\
\hline $\begin{array}{c}\text { Divalent cations } \\
\mathrm{CuSO}_{4}\end{array}$ & $\begin{array}{l}0.01 \\
0.10\end{array}$ & $\begin{array}{c}100 \\
70^{*}\end{array}$ \\
\hline $\mathrm{CoSO}_{4}$ & $\begin{array}{l}0.01 \\
0.10\end{array}$ & $\begin{array}{l}0.77 \\
0.29\end{array}$ \\
\hline $\mathrm{FeSO}_{4}$ & $\begin{array}{l}0.003 \\
0.10\end{array}$ & $\begin{array}{l}0.46 \\
0.50\end{array}$ \\
\hline $\mathrm{Hg}\left(\mathrm{CH}_{3} \mathrm{COO}\right)_{2}$ & 0.0006 & 60 \\
\hline $\mathrm{Hg}\left(\mathrm{NO}_{3}\right)_{2}$ & 0.0006 & 54 \\
\hline $\mathrm{MnSO}_{4}$ & $\begin{array}{l}0.003 \\
0.01\end{array}$ & $\begin{array}{l}99 \\
81\end{array}$ \\
\hline $\mathrm{NiCl}_{2}$ & 0.01 & 0.86 \\
\hline $\mathrm{Zn}\left(\mathrm{CH}_{3} \mathrm{COO}\right)_{2}$ & $\begin{array}{l}0.003 \\
0.01\end{array}$ & $\begin{array}{l}99 \\
90\end{array}$ \\
\hline $\begin{array}{l}\text { Trivalent cations } \\
\mathrm{AlCl}_{\mathbf{s}}\end{array}$ & 0.01 & 100 \\
\hline $\mathrm{AuCl}_{3}$ & 0.0006 & 58 \\
\hline CoNaNO, & 0.0006 & 28 \\
\hline $\mathrm{FeCl}_{3}$ & $\begin{array}{l}0.0001 \\
0.0004 \\
0.0006\end{array}$ & $\begin{array}{l}75 \\
50 \\
28\end{array}$ \\
\hline
\end{tabular}

assuming a non-fluorescent complex [Riboflavin - $\mathrm{Fe}^{\mathrm{III}}$ ] or one in which the lifetime of the excited state is very small compared to that of free riboflavin.

The effectiveness of $\mathrm{Fe}^{\mathrm{III}}$ as a quenching agent suggested that the quenching observed with $\mathrm{Fe}^{\mathrm{II}}$ ions (abnormally high for divalent compounds) might in part be due to the formation of $\mathrm{Fe}^{\mathrm{III}}$ ions. It was observed that with low concentrations $(<0.003 \mathrm{M})$ of $\mathrm{Fe}^{\mathrm{II}}$, unlike any of the other divalent ions tested, 


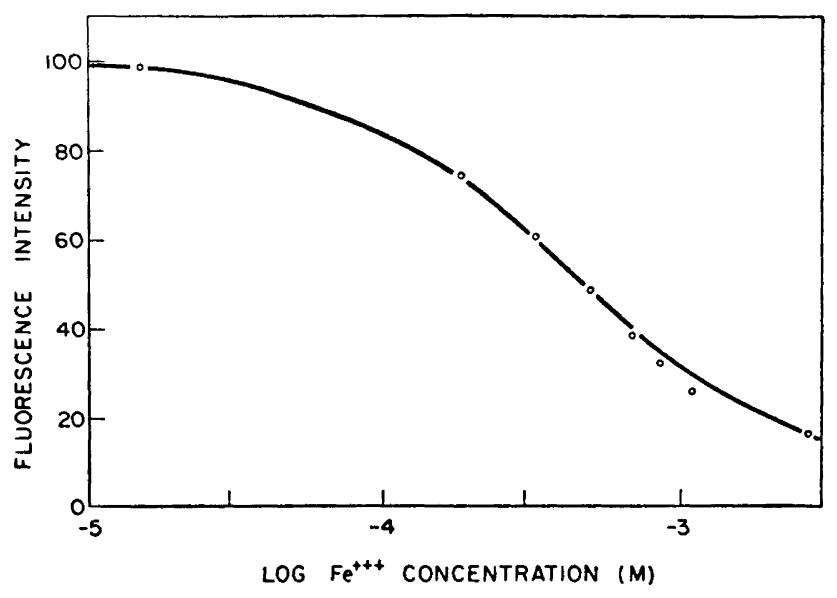

Fig. 1. Quenching of riboflavin fluorescence by $\mathrm{Fe}$ II ions. Experimental conditions as described under Table 1.

maximum quenching was obtained only after a considerable time lag (Fig. 2). At higher concentrations of $\mathrm{Fe}^{\text {II }}$, the degree of quenching did not change as a function of time; moreover the degree of quenching was approximately the same for $0.003 \mathrm{M}$ and $0.1 \mathrm{M} \mathrm{Fe}^{\mathrm{II}}$. Preincubation in the dark did not influence this characteristic behavior. These observations suggest either that $\mathrm{Fe}^{\mathrm{II}}$ itself is not a particularly effective quenching agent, but that it is converted to $\mathrm{Fe}^{\text {III }}$ during the course of the measurement of fluorescence, or alternatively that the

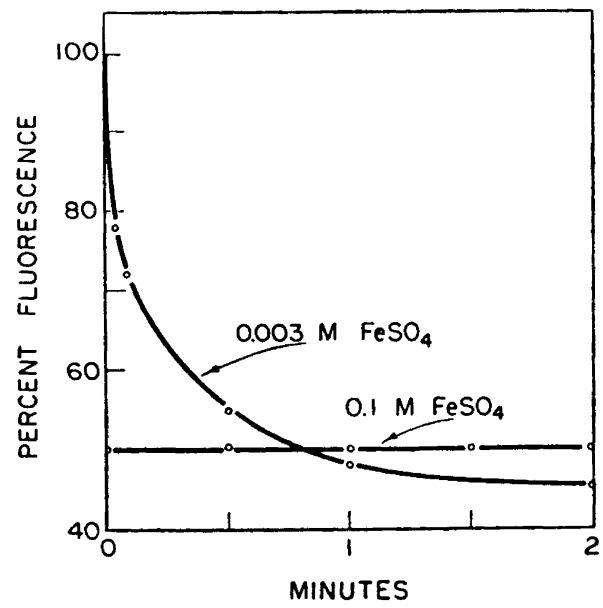

Fig. 2. Quenching of riboflavin fluorescence by FeUI ions. Riboflavin present at a final concentration of $10^{-6} \mathrm{M}, \mathrm{FeCl}_{3}$ added to the concentration indicated, pH adjusted to 5.5 with $\mathrm{NaHCO}_{3}$; temperature $30^{\circ} \mathrm{C}$. The per cent of fluorescence of the control riboflavin solution (no $\mathrm{FeCl}_{\mathrm{s}}$ added) is plotted as a function of $\mathrm{FeIII}$ present.

Acta Chem. Scand. 12 (1958) No. 3 


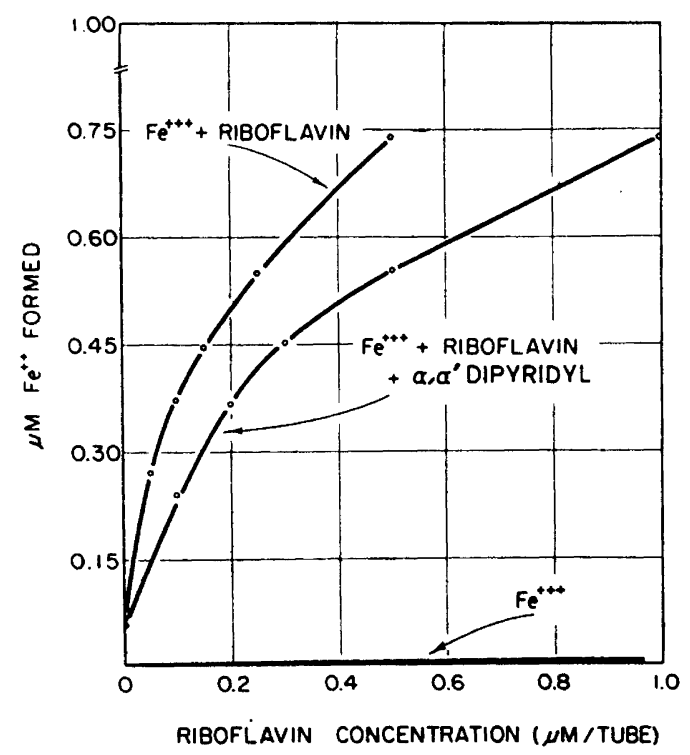

Fig. 3. Riboflavin catalysis of the photoreduction of $\mathrm{Fe}$ all experimental vessels; riboflavin at the concentration indicated; $100 \mathrm{mg} \alpha, \alpha^{\prime} \cdot$ dipyridyl was added in $0.1 \mathrm{ml}$ ethanol where indicated; $\mathrm{pH}$ adjusted to 5.5 in all vessels; period of irradiation, $10 \mathrm{~min}$; temperature $30^{\circ} \mathrm{C}$; nitrogen atmosphere. The values for FeII formation represent increments over FeII present in similar samples incubated in the dark.

final $\mathrm{Fe}$ II riboflavin complex (having about $50 \%$ of the original riboflavin fluorescence) is formed slowly, perhaps through several less stabile $\mathrm{Fe}^{\mathrm{II}}$ riboflavin complexes.

The other trivalent metal ions which showed inhibition of fluorescence roughly equivalent to $\mathrm{Fe}^{\mathrm{III}}$, also showed anomalous quenching behavior. In the experiments with $\mathrm{Co}^{\mathrm{III}}$ and $\mathrm{Au}^{\mathrm{III}}$, the quenching was strongest initially, and decreased with time to a constant level. These observations suggested that a secondary reaction was occurring: one possibility was that these compounds were being partially reduced to the divalent state. Further studies were made with $\mathrm{Fe}^{\mathrm{III}}$ first, because of the role of $\mathrm{Fe}$ in biological systems and secondly, because of the ease of detection of $\mathrm{Fe}^{\mathrm{II}}$ ions. Appropriate experiments demonstrated that there was indeed a riboflavin-catalyzed photooxidation of $\mathrm{Fe}^{\mathrm{II}}$, and a photoreduction of $\mathrm{Fe}^{\mathrm{III}}$.

Riboflavin-catalyzed photoreduction of $\mathrm{Fe}^{\mathrm{III}}$

After photoillumination of $\mathrm{Fe}^{\mathrm{III}}$ solutions, an increase in the $\mathrm{Fe}^{\mathrm{II}}$ concentration was detected in tubes to which riboflavin had been added. As shown in Fig. 3, the rate of formation of $\mathrm{Fe}^{\mathrm{II}}$ was proportional to the riboflavin present only at comparatively low riboflavin concentrations. The inhibition of $\mathrm{Fe}^{\mathrm{II}}$ formation by excess $\alpha, \alpha^{\prime}$-dipyridyl may be due to complexing with $\mathrm{Fe}^{\mathrm{III}}$ pre- 
Table 2. Effect of oxygen and catalase on riboflavin-catalyzed photoreduction. Experimental cuvettes contained $3 \mu \mathrm{M} \mathrm{FeCl}_{3}$ and $150 \mathrm{~m} \mu \mathrm{M}$ riboflavin and 150 units catalase as indicated; total volume $3.0 \mathrm{ml}$; $\mathrm{pH}$ 5.5; temperature $30^{\circ} \mathrm{C}$; illumination period $10 \mathrm{~min}$. The values presented are increments over non-illuminated controls.

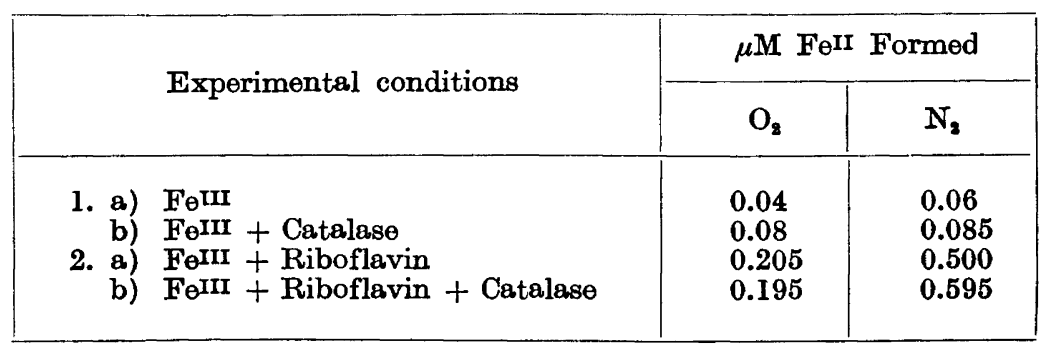

sent. Fig. 4 shows that the rate of formation of $\mathrm{Fe}^{\mathrm{II}}$ at a given riboflavin concentration decreases with time. This may be a result either of a conversion of riboflavin to a "less active" form, (e. g., formation of lumiflavin) or perhaps a reflection of approaching the steady state condition.

The data presented in Table 2 illustrate the effect of oxygen and catalase on the photoreduction of $\mathrm{Fe}^{\mathrm{III}}$ by this reaction. As might be expected, the net formation of $\mathrm{Fe}^{\mathrm{II}}$ from $\mathrm{Fe}^{\mathrm{III}}$ is diminished in the presence of oxygen. 10 to

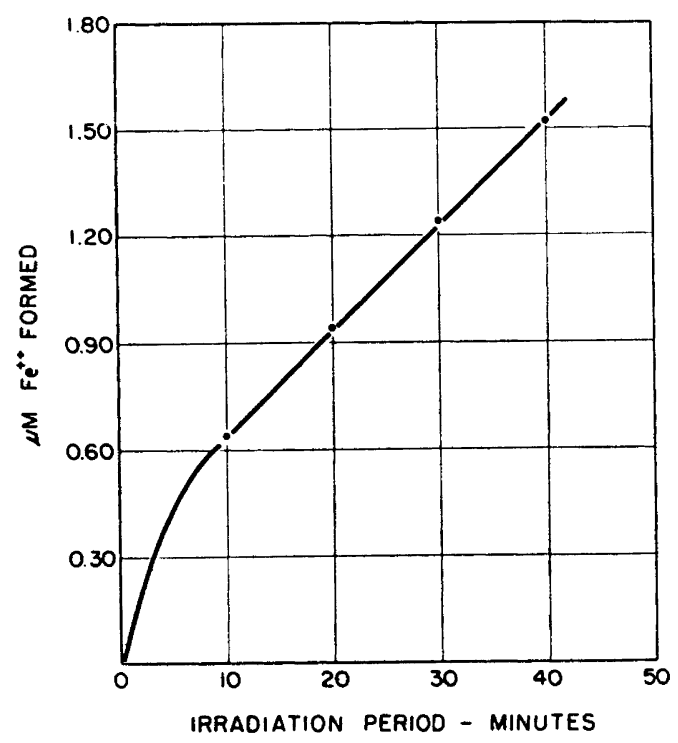

Fig. 4. Riboflavin catalysis of the photoreduction of FeIII as a function of the period of photoillumination. $2 \mu \mathrm{M} \mathrm{FeCl}$ and $1 \mu \mathrm{M}$ riboflavin; $100 \mathrm{mg} a, \alpha^{\prime}$-dipyridyl, $0.1 \mathrm{ml} 95 \%$ ethanol present in total volume of $3.0 \mathrm{ml}$; temperature $30.0^{\circ} \mathrm{C}$; nitrogen atmosphere. The values of $\mathrm{Fe}$ II formed are increments over FeII present in similar samples incubated in the dark. (Photoillumination of $\mathrm{Fe} I \mathrm{II}$ in the absence of riboflavin for a period of $40 \mathrm{~min}$ gives no change over a similar sample incubated in the dark).

Acta Chem. Scand. 12 (1958) No. 3 


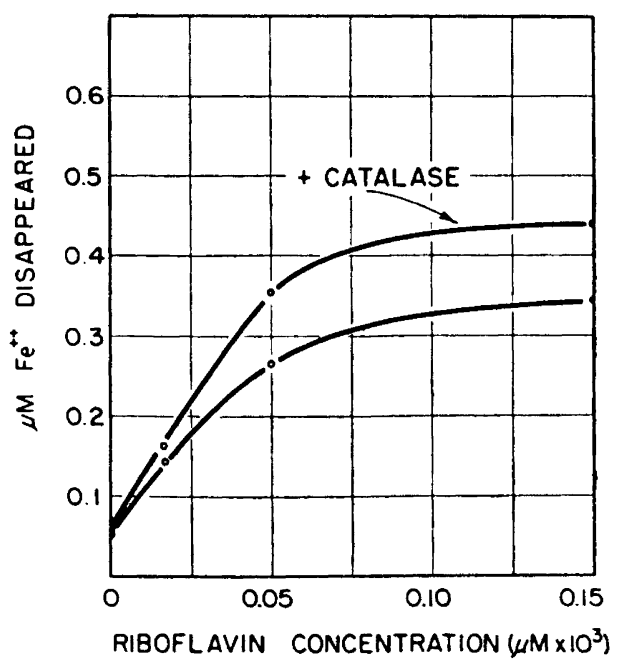

Fig. 5. Effect of catalase on riboflavin catalyzed photooxidation of FeII. $1 \mu \mathrm{M} \mathrm{FeSO}_{4}$; riboflavin in the concentration indicated, and sufficient crystalline catalase to decompose $50 \mathrm{mg} \mathrm{H}_{8} \mathrm{O}_{2}$ per min was added to each sample where indicated; final volume $3.0 \mathrm{ml}$; pH 5.5; temperature $30^{\circ} \mathrm{C}$; oxygen atmosphere; time of photoillumination, $10 \mathrm{~min}$.

$20 \%$ increase in $\mathrm{Fe}^{\mathrm{II}}$ formation were consistently observed in the presence of catalase.

Several attempts to obtain complete conversion of $\mathrm{Fe}^{\mathrm{III}}$ to $\mathrm{Fe}^{\mathrm{II}}$ by extended photoillumination periods and by large riboflavin/Fe ratios were unsuccessful. These observations prompted the question of the riboflavin catalysis of the photooxidation of $\mathrm{Fe}^{\mathrm{II}}$.

\section{Riboflavin-catalyzed photooxidation of $\mathrm{Fe}^{\mathrm{II}}$}

The effect of riboflavin on the photooxidation of $\mathrm{Fe}^{\mathrm{II}}$ salts is shown in Fig. 5. The values represent the difference between illuminated and nonilluminated samples. Catalase consistently stimulated the reaction by 15 to $35 \%$. The effect of oxygen on the course of the photooxidation is presented in Table 3. It is noteworthy that the absence of oxygen practically eliminates Fe ${ }^{\mathrm{II}}$ photooxidation. This observation together with that given in Table 2 for photoreduction of $\mathrm{Fe}^{\mathrm{III}}$ establishes the conditions under which photoreduction or photooxidation can predominate.

The possibility that riboflavin catalyzed oxidation of $\mathrm{Fe}^{\mathrm{II}}$ in the dark with oxygen as electron acceptor was tested. Under none of the conditions tested, could any facilitation of this reaction by riboflavin be detected. Even after incubation for $10 \mathrm{~h}$ in an oxygen atmosphere there was no difference in the rate of disappearance of $\mathrm{Fe}^{\mathrm{II}}$ in experimental vessels with riboflavin as compared to controls containing only $\mathrm{Fe}^{\mathrm{II}}$ ions. Spectral studies of riboflavin in the presence and absence of $\mathrm{Fe}^{\mathrm{II}}$ ions do not indicate the presence of detectable quantities of reduced riboflavin. During photoillumination there was, of 
Table 3. Effect of oxygen on riboflavin-catalyzed photo-oxidation of FeII. Each experimental cuvette contained $1 \mu \mathrm{M} \mathrm{FeSO}_{4}$ and $150 \mathrm{~m} \mu \mathrm{M}$ riboflavin when present. Total volume $30 \mathrm{ml}, \mathrm{pH} 5.5$, temperature $30^{\circ} \mathrm{C}$. The values presented are increments over non-illuminated controls.

\begin{tabular}{|l|c|c|c|}
\hline \multirow{2}{*}{ Additions } & $\begin{array}{c}\text { Photoillu- } \\
\text { mination } \\
\text { period }\end{array}$ & \multicolumn{2}{|c|}{$\mathrm{Fe}^{\mathrm{II}}$ Disappearance $(\mu \mathrm{M})$} \\
\cline { 3 - 4 } & & $\mathrm{O}_{2}$ & $\mathrm{~N}_{2}$ \\
\hline 1. $\mathrm{FeII}$ & 10 & 0.030 & 0.045 \\
2. FeII + Riboflavin & 30 & 0.046 & 0.050 \\
& 10 & 0.350 & 0.057 \\
& 20 & 0.437 & 0.067 \\
\hline
\end{tabular}

course, conversion of riboflavin to substances not absorbing in visible region, but this conversion was not markedly influenced by $\mathrm{Fe}^{\mathrm{II}}$ ions, and bubbling with oxygen did not regenerate the original riboflavin spectra.

\section{FMN and FAD catalyzed photoreduction of FerI and photooxidation of $\mathrm{Fe}^{\mathrm{II}}$}

Similar, but not so extensive studies indicate that FMN and FAD also catalyze photooxidation of $\mathrm{Fe}^{\mathrm{II}}$ and photoreduction of $\mathrm{Fe}^{\mathrm{III}}$ under similar conditions to those used in the riboflavin experiments.

\section{DISCUSSION}

It is known that riboflavin and FMN facilitate photooxidations and photoreductions. Recently Swallow ${ }^{11}$ has shown that X-ray irradiation of riboflavin solutions yields a free radical stable in acidic solution, spectrally like the compound produced by chemical reducing agents ${ }^{12}$. Merkel and Nickerson ${ }^{13}$ have demonstrated the photochemical reduction of riboflavin salts in aqueous systems containing riboflavin and certain other compounds, e. g., $\mathrm{Na}_{2} \mathrm{EDTA}$, ethylene diamine, cysteine, mercapto succinic, and carboxymethyl succinic acids. Andreae ${ }^{14}$ has shown a net formation of $\mathrm{Mn}^{\mathrm{III}}$ ions upon irradiation of solutions containing $\mathrm{Mn}^{\mathrm{II}}$, pyrophosphate, one of a variety of phenols, and riboflavin. Vernon and Ihnen ${ }^{15}$ have reported a riboflavin or FMN catalyzed photochemical oxidation of 2,6-dichlorophenol-indophenol and reduced cytochrome c.

The riboflavin catalyzed photochemical oxidation-reduction system reported here is perhaps more easily studied because it is uncomplicated in the sense that a reaction can be observed in aqueous solutions containing only riboflavin and $\mathrm{Fe}^{\mathrm{II}}$ or $\mathrm{Fe}^{\mathrm{III}}$, and because the system is reversible. (This does not necessarily imply that the reduction of $\mathrm{Fe}^{\mathrm{III}}$ proceeds by a reversal of the same pathway involved in the oxidation of $\mathrm{Fe}^{\mathrm{II}}$ ).

The data obtained are consistent with, but do not prove the postulated series of reactions.

Acta Chem. Scand. 12 (1918) No. 3 


$$
\begin{aligned}
& \mathrm{R} \stackrel{h \nu}{\longrightarrow} \mathrm{R}^{*} \\
& \mathrm{R}^{*}+2 \mathrm{H}_{2} \mathrm{O} \stackrel{\text { slow }}{\longrightarrow} \mathrm{RH}_{2}+2{ }^{\circ} \mathrm{OH} \\
& \mathrm{R}^{*}+2 \mathrm{H}^{+}+2 \mathrm{Fe}^{\mathrm{II}} \rightarrow \mathrm{RH}_{2}+2 \mathrm{Fe}^{\mathrm{III}} \\
& \mathrm{RH}_{2}+\mathrm{O}_{2} \stackrel{\text { fast }}{\longrightarrow} \mathrm{R}+\mathrm{H}_{2} \mathrm{O}_{2} \\
& \mathrm{RH}_{2}+2 \mathrm{Fe}^{\mathrm{III}} \stackrel{\text { fast }}{\longrightarrow} \mathrm{R}+2 \mathrm{Fe}^{\mathrm{II}}+2 \mathrm{H}^{+} \\
& \text {overall reaction for oxidation of } \mathrm{Fe}^{\mathrm{II}} \\
& 2 \mathrm{H}^{+}+2 \mathrm{Fe}^{\mathrm{II}}+\mathrm{O}_{2} \stackrel{h \nu}{\longrightarrow} 2 \mathrm{Fe}^{\mathrm{III}}+\mathrm{H}_{2} \mathrm{O}_{2}
\end{aligned}
$$

overall reaction for reduction of $\mathrm{Fe}^{\mathrm{III}}$

$2 \mathrm{H}_{2} \mathrm{O}+2 \mathrm{Fe}^{\mathrm{III}} \stackrel{h \nu}{\longrightarrow} 2 \mathrm{Fe}^{\mathrm{II}}+\mathrm{H}_{2} \mathrm{O}_{2}+2 \mathrm{H}^{+}$

( $\mathrm{R}=$ riboflavin; $\mathrm{RH}_{2}=$ reduced riboflavin; $h v=$ photoelectric energy)

The reactions listed should be considered only as one possible formal description of the observations reported.

The interesting observations of Merkel and Nickerson mentioned earlier can perhaps be most easily interpreted in terms of a reaction like (3) above in which the metal chelate acts as an electron donor to riboflavin in the presence of light-energy.

The possible relationship of the present photochemical reactions to the function of riboflavin in biological systems is worthy of consideration. The present observations are most readily explained in terms of a direct electron transference between riboflavin and $\mathrm{Fe}$, and as such, are pertinent to the proposed mechanisms of action of certain of the flavoproteins. The possibility of a role of $\mathrm{Fe}$ and riboflavin in photobiologic processes should also not be overlooked.

Acknowledgment. The author wishes to express appreciation to Professor Theorell for his active interest in this work and for the gracious hospitality extended by him and other members of the Biochemical Department.

\section{REFERENCES}

1. Theorell, H. in Sumner, J. B. and Myrbäck, K. The Enzymes, Vol. II, part I, Academic Press, New York 1951, p. 335.

2. Singer, T. P., and Kearney, E. B. in Neurath, H. and Bailey, K. The Proteins Vol. II, part A, Academic Press, New York 1954, p. 124.

3. Mahler, H. Advances in Enzymol. 17 (1956) 223.

4. Weber, M. M., Lenhoff, H. M. and Kaplan, N. O. J. Biol. Chem. 220 (1956) 93.

5. Beers, R. F., Jr. and Sizer, I. W. J. Biol. Chem. 195 (1952) 133.

6. Feigl, F. Spot Tests, Elsevier Publishing Co., Amsterdam 1954, p. 154.

7. Theorell, H. and Nygaard, A. P. Acta Chem. Scand. 8 (1954) 877.

8. Weber, G. Biochem. J. 47 (1950) 114.

9. Theorell, H. and Nygaard, A. P. Arkiv Kemi 1 (1954) 205.

10. Albert, A. Biochem. J. 54 (1953) 646.

11. Swallow, A. J. Nature 176 (1955) 793.

12. Kuhn, R. and Wagner-Jauregg, T. Ber. 67 (1934) 361.

13. Merkel, J. R. and Nickerson, W. J. Biochim. et Biophys. Acta 14 (1954) 303.

14. Andreae, W. A. Arch. Biochem. Biophys. 55 (1955) 584.

15. Vernon, L. P. and Thnen, E. D. Biochim. et Biophys. Acta 24 (1957) 115. 